\title{
PENANGANAN KONFLIK SOSIAL DENGAN PENDEKATAN KEADILAN RESTORATIF
}

\author{
Sukardi* \\ * Penyidik Sub Direktorat Anti Money Laundering Direktorat Tindak Pidana Ekonomi dan Khusus \\ Bareskrim Polri, Dosen Luar Biasa Hukum Pidana FH Universitas Hasanuddin, Makassar \\ Korespondensi: sukardi.s3unhas@gmail.com \\ Naskah dikirim: 27 Januari 2016 \\ Naskah diterima untuk diterbitkan: 9 Maret 2016
}

\begin{abstract}
Restorative Justice approach in conflict resolution is basically a new method of settling disputes, especially in the concept-criminal cases, but using traditional patterns whose values have no concept of local wisdom in each culture. Therefore, the application of restorative justice approach in conflict resolution, in fact is the use of traditional patterns with the values of the resolution of the existing conflicts in wisdom local culture, with a focus on fulfillment of justice victims, through the concept of equality, partnership, reconciliation and participation.
\end{abstract}

Keyword: social conflict, restoratif justice, local wisdom

\begin{abstract}
Abstrak
Pendekatan Keadilan Restoratif dalam resolusi konflik pada dasarnya adalah sebuah metode baru untuk menyelesaikan sengketa, terutama dalam kasuskasus konsep-kriminal, tetapi menggunakan pola tradisional yang nilainya tidak memiliki konsep kearifan lokal di masing-masing budaya. Oleh karena itu, penerapan pendekatan keadilan restoratif dalam resolusi konflik, sebenarnya adalah penggunaan pola tradisional dengan nilai-nilai resolusi konflik yang ada dalam kebijaksanaan budaya lokal, dengan fokus pada pemenuhan korban keadilan, melalui konsep kesetaraan, kemitraan, rekonsiliasi dan partisipasi.
\end{abstract}

Kata kunci: konflik sosial, keadilan restoratif, kearifan lokal

\section{Pendahuluan}

Sejak awal kemerdekaan Indonesia pada tanggal 17 Agustus 1945 telah diletakkan dasar konstitusional yaitu UUD 1945 sebagai landasan hukum tertinggi di Negara ini. Di dalam penjelasan umum UUD 1945 ditegaskan bahwa sistem pemerintahan Indonesia salah satunya adalah bahwa Indonesia, 
ialah Negara yang berdasar atas Hukum (Rechsstaat), ${ }^{1}$ tidak berdasar atas kekuasaan belaka (Machtsstaat). Implementasi konsep Negara hukum dalam praktek penyelenggaraan Negara tersebut, menempatkan hukum sebagai panglima dalam rangka mewujudkan tujuan Negara. ${ }^{2}$ Hukum adalah supreme yang harus ditaati oleh setiap warga Negara dan harus ditegakkan oleh Negara dalam rangka kehidupan berbangsa, bernegara dan bermasyarakat.

Landasan konstitusional tersebut memberikan pemahaman bahwa penyelenggaraan Negara Indonesia adalah di dasarkan pada konsep hukum. Peran hukum dalam era reformasi di segala bidang ilmu merupakan bukti nyata, secara hakiki kehidupan masyarakat memerlukan seperangkat aturan hukum yang selalu dapat menjaga ketertiban dan lebih jauh lagi memberikan kepastian hukum, kemanfaatan dan keadilan. ${ }^{3}$

Perkembangan sosial politik di Indonesia sejak kemerdekaan 17 Agustus 1945 hingga lahirnya era Reformasi, menunjukkan adanya kecenderungan untuk membangun suatu kondisi apa yang disebut sebagai masyarakat madani atau civil society, meskipun berbagai faktor yang menjadi kendala masih tetap mewarnai fonomena kehidupan berbangsa dan bernegara hingga saat ini. Karena itu banyak kalangan yang menilai bahwa untuk menciptakan civil society di Indonesia tidak mudah dan memerlukan waktu yang tidak sedikit.

Salah satu ide penting yang melekat dalam konsep civil society menurut Seligman Adam dalam bukunya "The Idea of Civil Society" adalah bahwa keinginan memperbaiki kualitas hubungan antara masyarakat dengan institusi sosial yang berada pada sektor publik dalam hal ini pemerintah dan partai politik, kemudian sektor swasta atau pelaku bisnis serta sektor sukarela yaitu lembaga swadaya masyarakat, organisasi keagamaan dan kelompok profesional. ${ }^{4}$ Secara politis, konsep civil society dapat membentuk hubungan semetris dan kondusif bagi terciptanya demokrasi, sedangkan secara sosial,

\footnotetext{
${ }^{1}$ Istilah rechtsstaat (negara hukum) merupakan istilah baru, baik jika dibandingkan dengan istilah demokrasi, konstitusi, maupun kedaulatan rakyat. Para ahli telah memberikan pengertian tentang negara hukum. R. Supomo misalnya memberikan pengertian terhadap negara hukum sebagai negara yang tunduk pada hukum, peraturan-peraturan hukum berlaku pula bagi segala badan dan alat-alat perlengkapan negara. Negar hukum juga akan menjamin tertib hukum dalam masyarakat yang artinya memberikan perlindungan hukum, antara hukum dan kekuasaan ada hubungan timbal balik. Lihat Mukthi Fadjar, “Tipe Negara Hukum”, (Malang: Bayu Media dan In-TRANS, 2004), hal 7.

${ }^{2}$ Tujuan negara berdasarkan Pembukaan UUD 1945 adalah untuk: “...melindungi segenap bangsa Indonesia dan seluruh tumpah darah Indonesia dan untuk memajukan kesejahteraan umum, mencerdaskan kehidupan bangsa, dan ikut melaksanakan ketertiban dunia yang berdasarkan kemerdekaan, perdamaian abadi dan keadilan sosial...”.

${ }^{3}$ Aminuddin Ilmar, "Konstruksi Teori dan Metode Kajian Ilmu Hukum”, (Makassar: Hasanuddin University Press, 2009), hal. 3. Teori tujuan hukum oleh Gustav Radbruch seorang filsuf Jerman yang mengajarkan teori "ide des recht" atau tiga ide unsur dasar hukum yang sebagian pihak mengidentikkan dengan tiga tujuan hukum yaitu: keadilan, kemanfaatan dan kepastian hukum.

${ }^{4}$ Sunyoto Usman, Peran Civil Society (Masyarakat Madani) dalam Tata Pemerintahan, Makalah disampaikan pada seminar "Membangun Kemitraan antara Pemerintah dan Masyarakat Madani untuk Mewujudkan Tata Pemerintahan yang Baik", diselenggarakan oleh Badan Perencanaan Pembangunan Nasional, Jakarta, 9 Oktober 2001, hal. 1.
} 
civil society membangun keseimbangan kedudukan dan peran orang sebagai individu dan sebagai anggota masyarakat, atau keseimbangan antara individual participation dan social obligations. ${ }^{5}$

Fenomena perkembangan kehidupan manusia tersebut di atas, berdampak pada timbulnya perubahan dalam struktur kehidupan sosial, termasuk di dalamnya perubahan dalam bidang hukum yang bukan hanya mencakup perubahan struktur dan substansi hukumnya akan tetapi juga menyangkut perubahan kultur hukum. ${ }^{6}$ Konsekwensi logis dari perubahan sosial tersebut di atas seringkali menimbulkan conflict of interest yang memunculkan berbagai pola-pola baru dalam kehidupan sosial untuk mempertahankan hidup (survive). Perubahan-perubahan yang serba cepat ditengah perbedaan kebudayaan, mengakibatkan ketidak mampuan banyak individu untuk menyesuaikan diri, mengakibatkan timbulnya disharmoni, konflik-konflik eksternal dan internal, juga disorganisasi dalam masyarakat dan diri pribadi serta timbulnya kesenjangan sosial, ekonomi, hukum yang tidak sedikit mempengaruhi aspek politik. Peristiwa-peristiwa tersebut memudahkan individu menggunakan polapola responsive atau reaksi yang inkonvensional atau menyimpang dari polapola umum.

Salah satu dampak negatif dari perkembangan yang tidak seimbang dalam kehidupan sosial kemasyarakatan adalah munculnya konflik sosial baik vertikal maupun horizontal. Menurut Seta Basri bahwa ${ }^{7}$ Konflik-konflik yang terjadi di Indonesia umumnya berkembang di sekeliling garis multikulturalitas masyarakat. Nuansa suku bangsa, etnis, agama, dan pelapisan sosial mewarnai konflik-konflik violence sekaligus vandal. Konflik yang menyeret wacana primordial umum terjadi dalam konflik-konflik di Kalimantan (antara etnis Madura, Melayu, dan Dayak), di Ambon, Poso, dan Halmahera (kaum migran, pribumi, Muslim, Nasrani, klien-klien elit politik), kerusuhan sosial dan etnis Mei 1998 di Jakarta, konflik Aceh, serta pembantaian 1966 di Jawa dan Bali, adalah sebagian konflik dalam aras ini.

Konflik horizontal seringkali terkait dengan tindakan kekerasan (violance). Bahkan dalam perkembangan sosial masyarakat yang mengarah ke demokratisasi seringkali diwarnai dengan berbagai peristiwa anarkis yang justru berangkat dari rendahnya trust masyarakat terhadap pemerintah. Konsep demokrasi dalam konteks masyarakat madani seperti menyampaikan pendapat di muka umum, Unjuk rasa dan sebagainya, secara normative adalah penyampaian aspirasi secara damai. Hal ini sejalan dengan ciri atau indikator dari konsep masyarakat madani yaitu demokratis, taat hukum, berkeadilan, berkesetaraan, toleran, dan menghargai hak asasi manusia.

\footnotetext{
${ }^{5}$ Ibid., hal. 1.

${ }^{6}$ Friedman, "Law and Society”, (New Jersey: Prentice-Hall, 1997), hal. 6 - 9, Satjipto Rahardjo, "Ilmu Hukum", (Bandung: PT. Citra Aditya Bhakti, 2000), hal. 154. "Bahwa hukum itu tidak layak hanya dibicarakan dari segi struktur dan substansinya saja, melainkan juga dari segi kultur hukumnya.

7 Seta Basri, Konflik Vertikal dan Horizontal di Indonesia, <http://setabasri01.blogspot.com/ 2012/05/pendekatan-pendekatan-dalam.html>, diakses tanggal 12 September 2012.
} 
Berbagai pemerintah dalam rangka upaya penanggulangan konflik baik dalam rangka pencegahan konflik, penghentian konflik maupun upaya pemulihan pasca konflik. Upaya pemerintah ini kemudian dirumuskan dalam UU No. 7 Tahun 2012 tentang Penanganan konflik Sosial. ${ }^{8}$ Pemerintah membangun sistem kelembagaan dalam upaya penanganan konflik sosial dalam ketentuan Undang-Undang tersebut dengan melibatkan semua komponen masyarakat untuk secara bersama-sama menyatukan visi dan misi untuk melakukan upaya penanggulangan konflik. Bahkan dalam konsep penaggulangan konflik tersebut, pemerintah mengakui eksistensi pranata adat dan pranata sosial yang ada, serta memberdayakan untuk melakukan langkahlangkah penaggulangan konflik bersama-sama pemerintah.

Pergeseran paradigma pemidanaan dan konsep keadilan dalam penegakan hukum pidana di berbagai Negara saat ini ditandai dengan menguatnya dukungan terhadap penerapan konsep restorative justice, ${ }^{9}$ untuk menggantikan konsep restitutif justice (criminal justice). Ahmad Ali menyebut restorative justice ini sebagai konsep modern hukum pidana. ${ }^{10}$ Meskipun menurut Braithwaite bahwa para pendukung konsep ini, menyatakan bahwa penerapan konsep restorative justice berarti kembali ke pola penyelesaian perkara pidana secara primitif/tradisional. ${ }^{11}$

Pendekatan prinsip restorative justice (keadilan restoratif) dalam penyelesaian perkara pidana (penal) dianggap sebagai suatu metode baru, meskipun pola-pola yang digunakan sebagian besar telah mengakar dalam nilai-nilai kearifan lokal masyarakat primitif. Braithwaite, J (2002) menyatakan

${ }^{8}$ Lembaran Negara Republik Indonesia Tahun 2012 Nomor 116, Tambahan Lembaran Negara Nomor 5313., diundangkan pada tanggal 10 Mei 2012.

${ }^{9}$ Konsep Restorative Justice diperkenalkan oleh Braithwaite pada tahun 1980an, sebagai pendekatan dalam sistem penghukuman, karena terinspirasi oleh masyarakat Maori dalam menangani penyimpangan di lingkungan mereka, yang menekankan penyelesaian masalah dengan melibatkan masyarakat dan petinggi masyarakat setempat untuk menyelsaikan masalah secara kekeluargaan. Lihat Manshur Zikri, 1 Juni 2011, Restorative Justice Sebagai Mekanisme Penyelesaian Perkara Yang Mengedepankan Kepentingan Perempuan Sebagai Korban Kekerasan Seksual, $<$ http://manshurzikri.wordpress.com/2011/06/01/restorative-justice-sebagai-mekanisme-penyelesaianperkara-yang-menge-depankan-kepentingan-perempuan-sebagai-korban-kekerasan-seksual/>, diakses tanggal 25 September 2011

${ }^{10}$ Ahmad Ali, 21 Desember 2011, Restorative (RJ) adalah konsep Modern Hukum Pidana, Harian Fajar, Makassar, Hal 4 kolom 1. Dalam tulisannya tersebut Ahmad Ali mengutip definisi restorative justice dari buku Dictionary of conflict resolution, compiled and edited by Douglash, Yrn, 1999 ; p. 381 yaitu : "Restorative justice is criminal justice concept that views crime as violation of people, not as a violation of the state, and creates an obligation to the victim and to the community to make things right. It focuses on the crime's harm rather than on the broken rule and emphasizes redress for the victim and the community for the effects of the wrong doing over punishment imposed by the state. Restorative justice models may provide for appropriate dialogue, direct or indirect, between the victim and offender in the form of victim-offender mediation".

${ }^{11}$ Menurut Braithwaite bahwa: “according to its proponent, restorative justice is not a new invention. Rather, it is a return to traditional pattern of dealing with conflict and crime that had been present in different cultures throughout human history. Braithwaite, J., "Restorative Justice and Responsive Regulation”, (USA: Oxford University Press, 2002), p. 1. Lihat juga Margarita Zernova, "Restorative Justice, Ideals and Realities", (Ashgate Publishing Limited, 2007), p. 7. 
bahwa: "restorative justice is not a new invention. Rather, it is a return to traditional pattern of dealing with conflict and crime that had been present in different cultures throughout human history." 12 Howard Zehr memaknai restorative justice sebagai proses untuk melibatkan pihak-pihak yang mempunyai kepentingan atas suatu pelanggaran yang spesifik, kemudian secara bersama, mengidentifikasi dan mengarahkan kerugian, kebutuhan, dan kewajiban dalam rangka menyembuhkan dan menempatkan hak para pihak sebagai titik yang mungkin dituju untuk diselesaikan. ${ }^{13}$ Kemudian menurut Sharpe ${ }^{14}$ bahwa keadilan restoratif memiliki karakteristik yang fundamental dengan beragam nilai yang disebut dengan pengikutsertaan (partisipasi), demokrasi, tanggung jawab, pemulihan, keamanan, penyembuhan, dan reintegrasi.

Menurut Sukardi bahwa: ${ }^{15}$

The restorative justice principle is an approach which is more focused on creating conditions of harmonization and balanced justice for the victim and the perpetrator of crime. The criminalization oriented mechanism of criminal procedure and justice is shifted to the process of dialogue and mediation with an orientation towards the restoration of justice for victims and reaching an agreement for a more just and balanced criminal case settlement for the victim and the offender concerned."

Konsep pendekatan restorative justice pada dasarnya merupakan suatu pendekatan yang lebih menitik beratkan pada pemulihan kerugian dan penderitaan korban sehingga terciptanya keadilan dan keseimbangan bagi pelaku tindak pidana serta korbannya.

Berdasarkan uraian tersebut di atas, maka menarik bagi penulis untuk mengkaji pendekatan keadilan restoratif dalam penyelesaian konflik sosial, dengan persfektif bahwa konflik sosial pada dasarnya berakar pada social problem yang ada dalam masyarakat, sedangkan pendekatan keadilan restoratif merupakan pola yang kembali pada kearifan lokal masing-masing daerah.

\footnotetext{
${ }^{12}$ Braithwaite Ibid., hal. 7.

13 Sukardi, Perspektif Hukum Refleksif Terhadap Konsep Restorative Justice Dalam Pembaharuan Hukum Pidana, "Jurnal Ilmu Hukum Ammana Gappa", Universitas Hasanuddin Makassar Vol. 20 Nomor 2 Juni 2012, Makassar, hal. 4.

14 Yayasan Pemantau Hak Anak, Children's Human Rights Foundation, Anak yang Berhadapan dengan Hukum dalam Perspektif Hukum Hak Asasi Manusia Internasional, hal. 8.

${ }^{15}$ Sukardi, 2014, Legitimacy of The Restorative Justice Principle in the Context of Criminal Law Enforcement, "Indonesia Law Review", Vol. 4 Number 2 May-August 2014, Universitas Indonesia ISSN 2088-8430, e-ISSN 2356-2129, hal. 8.
} 


\section{Permasalahan}

Bagaimana konsep pendekatan keadilan restoratif dalam penyelesaian konflik sosial?

\section{Metode Penelitian}

Jenis penelitian dalam tulisan ini adalah penelitian normatif, yang mengkaji konsep penyidikan tindak pidana dan prinsip restorative justice dari persfektif sistem hukum pidana Indonesia, sehingga dapat dikonstruksi konsep penyidikan restorative justice yang ideal diterapkan dalam penegakan hukum pidana di Indonesia.

Data yang digunakan berupa data sekunder yang terdiri dari bahan-bahan hukum primer berupa peraturan perundang-undangan, bahan hukum tersier berupa buku-buku referensi, pendapat ahli maupun hasil penelitian terdahulu, dan bahan hukum tersier berupa kamus-kamus bahasa, kamus ilmiah hukum dan black law dictionary.

Metode analisis dalam penulisan ini dimulai dengan mengabstraksi bahan-bahan hukum primer, bahan hukum sekunder dan bahan hukum tersier, sehingga dapat dikonstruksi konsep penyidikan dan prinsip restorative justice, teori-teori hukum pidana, menganalisis kelemahan-kelemahan prinsip restorative dari persfektif penegakan hukum pidana, melakukan sistematisasi, dan terakhir dengan menggunakan metode penalaran silogisme deduktif.

\section{Pembahasan}

\section{Konflik Horizontal}

Kehidupan bangsa Indonesia dewasa ini tengah menghadapi ancaman serius berkaitan dengan munculnya konflik-konflik dalam masyarakat, baik yang bersifat vertikal maupun horizontal. Kemajemukan bangsa yang seharusnya dapat kondusif bagi pengembangan demokrasi ditenggelamkan oleh ideologi harmoni sosial yang serba semu, yang tidak lain adalah ideologi keseragaman. Kemajemukan pada dasarnya juga dapat berpotensi mengganggu stabilitas politik, jika tidak dikelola dengan baik. Karena itu negara perlu menyeragamkan setiap elemen kemajemukan dalam masyarakat sesuai dengan karsanya, tanpa harus merasa telah mengingkari prinsip dasar hidup bersama dalam keberagaman. Dengan segala kekuasaan yang ada padanya negara tidak segan-segan untuk menggunakan cara-cara koersif agar masyarakat tunduk pada ideologi negara yang maunya serba seragam, serba tunggal. Perlakuan Negara yang demikian diapresiasi dan diinternalisasi oleh masyarakat dalam kesadaran sosial politiknya. Pada gilirannya kesadaran yang bias state itu mengarahkan sikap dan perilaku sosial masyarakat kepada hal-hal yang bersifat diskriminatif, kekerasan, dan dehumanisasi. Hal itu dapat kita saksikan dari kecenderungan xenophobia dalam masyarakat ketika berhadapan dengan 
elemen-elemen pluralitas bangsa. Penerimaan masyarakat terhadap pluralitas kurang lebih sama dan sebangun dengan penerimaan negara atas fakta sosiologis-kultural itu. Karena itu, subyektivitas masyarakat kian menonjol dan pada gilirannya menafikan kelompok lain yang dalam alam pikirnya diyakini "berbeda". Dari sinilah konflik-konflik sosial politik memperoleh legitimasi rasionalnya. ${ }^{16}$

Dalam konteks ini, negara patut diletakkan sebagai faktor dominan yang telah membentuk pola pikir dan kesadaran anti demokrasi di kalangan masyarakat. Ketika negara mengalami defisit otoritas, kesadaran bias state masyarakat semakin menonjol dalam pelbagai pola perilaku sosial dan politik. Munculnya reformasi telah menyediakan ruang yang lebih lebar bagi artikulasi pendapat dan kepentingan masyarakat pada umumnya. Masalahnya, artikulasi pendapat dan kepentingan itu masih belum terlepas dari kesadaran bias state yang mengimplikasikan dehumanisasi.

Istilah konflik itu sendiri seringkali diartikan sebagai lawan kata dari pengertian keserasian, kedamaian, dan keteraturan. Konflik seringkali diasosiasikan dengan kekerasan atau ancaman kekerasan. Pandangan yang sempit mengenai konflik yang demikian, tidak mudah untuk diubah. Munculnya budaya "mencegah konflik", "meredam konflik" dan anggapan bahwa berkonflik adalah "berkelahi" bukanlah sesuatu yang relevan untuk kondisi saat ini. Konflik bukanlah sesuatu yang dapat dihindari atau disembunyikan, tetapi harus diakui keberadaannya, dikelola, dan diubah menjadi suatu kekuatan bagi perubahan positif.17

Konflik berasal dari kata kerja Latin "configure" yang berarti saling memukul. Secara sosiologis, konflik diartikan sebagai suatu proses sosial antara dua orang atau lebih (bisa juga kelompok) dimana salah satu pihak berusaha menyingkirkan pihak lain dengan menghancurkannya atau membuatnya tidak berdaya. Konflik dilatarbelakangi oleh perbedaan ciri-ciri yang dibawa individu dalam suatu interaksi. perbedaan-perbedaan tersebut diantaranya adalah menyangkut ciri fisik, kepandaian, pengetahuan, adat istiadat, keyakinan, dan lain sebagainya. Konflik adalah sesuatu yang wajar terjadi di masyarakat, konflik hanya akan hilang bersamaan dengan hilangnya masyarakat itu sendiri. Konflik bertentangan dengan integrasi. Konflik dan Integrasi berjalan sebagai sebuah siklus di masyarakat. Konflik yang terkontrol akan menghasilkan integrasi. sebaliknya, integrasi yang tidak sempurna dapat menciptakan konflik. ${ }^{18}$

Konflik perlu dimaknai sebagai suatu jalan atau sarana menuju perubahan masyarakat. Keterbukaan dan keseriusan dalam mengurai akar permasalahan konflik dan komunikasi yang baik dan terbuka antar pihak yang

${ }^{16}$ Scribd.com, Konflik Sosial di Indonesia, <http://www.scribd.com /doc/54153599/7-KonflikSosial-Di-Indonesia>, diakses tanggal 12 Desember 2012.

17 Wahyoefiles, Konflik dan cara Penbyelesaiannya, <http://www.wahyoefiles.web.id/ 2010/11/konflik-dan-cara-penbyelesaiannya.html>, diakses tanggal 12 September 2012.

\footnotetext{
${ }^{18}$ Scribd.com, Op. Cit.
} 
berkepentingan merupakan cara penanganan konflik yang perlu dikedepankan. Adanya data dan informasi yang jujur dan dapat dipahami oleh semua pihak yang berkepentingan merupakan syarat bagi terjalinnya komunikasi di atas. Keragaman budaya yang ada bisa juga berarti keragaman nilai-nilai. Keragaman nilai bangsa kita seharusnya dipandang sebagai modal bangsa, bukan sebagai sumber konflik. Interaksi lintas budaya yang apresiatif dan komunikatif dapat melahirkan proses sintesa-sintesa budaya. Budaya yang universal yang lebih dapat menaungi komunitas yang lebih besar, ataupun berkembanganya suatu sistem nilai (budaya) tertentu sebagai akibat "sentuhansentuhan" dengan sistem nilai (budaya) tertentu, adalah sesuatu yang kita harapkan.

Ada beberapa Pandangan tentang Konflik yang dkemukakan oleh para pakar diantaranya sebagai berikut ${ }^{: 19}$

a. Konflik adalah bentuk pertentangan alamiah yang dihasilkan oleh individu atau kelompok karena mereka yang terlibat memiliki perbedaan sikap, kepercayaan, nilai-nilai, serta kebutuhan;

b. Hubungan pertentangan antara dua pihak atau lebih (individu maupun kelompok) yang memiliki atau merasa memiliki sasaransasaran tertentu, namun diliputi pemikiran, perasaan, atau perbuatan yang tidak sejalan;

c. Pertentangan atau pertikaian karena ada perbedaan dalam kebutuhan, nilai, dan motifasi pelaku atau yang terlibat di dalamnya;

d. Suatu proses yang terjadi ketika satu pihak secara negatif mempengaruhi pihak lain, dengan melakukan kekerasan fisik yang membuat orang lain perasaan serta fisiknya terganggu;

e. Suatu bentuk perlawanan yang melibatkan dua pihak secara antagonis;

f. Kekacauan rangsangan kontradiktif dalam diri individu.

Di dalam rumusan Pasal 1 butir 1 UU No. 7 Tahun 2012 tentang Penanganan Konflik Sosial, dijelaskan bahwa yang dimaksud dengan konflik sosial yang dalam UU tersebut disebut konflik adalah: "perseteruan dan/atau benturan fisik dengan kekerasan antara dua kelompok masyarakat atau lebih yang berlangsung dalam waktu tertentu dan berdampak luas yang mengakibatkan ketidaknyamanan dan disintegrasi sosial sehingga mengganggu stabilitas nasional dan menghambat pembangunan nasional."

\section{Faktor Penyebab dan Jenis-jenis Konflik}

Faktor penyebab konflik adalah Perbedaan individu yang meliputi perbedaan pendirian dan perasaan. Perbedaan latar belakang kebudayaan sehingga membentuk pribadi-pribadi yang berbeda pula. seseorang sedikit banyak akan terpengaruh dengan pola-pola pemikiran dan pendirian kelompoknya. 
a. Perbedaan kepentingan antara individu atau kelompok, diantaranya menyangkut bidang ekonomi, politik, dan sosial.

b. Perubahan-perubahan nilai yang cepat dan mendadak dalam masyarakat.

Sedangkan jenis-jenis konflik Menurut Dahrendorf, konflik dibedakan menjadi 4 macam:

a. konflik antara atau dalam peran sosial (intrapribadi), misalnya antara peranan-peranan dalam keluarga atau profesi (konflik peran (role).

b. konflik antara kelompok-kelompok sosial (antar keluarga, antar gank).

c. konflik kelompok terorganisir dan tidak terorganisir (polisi melawan massa).

d. konflik antar satuan nasional (kampanye, perang saudara).

Berdasarkan ketentuan dalam Pasal 5 UU No. 7 Tahun 2012 tentang Penanganan Konflik Sosial, maka sumber-sumber konflik dapat berupa:

a. Permasalahan yang berkaitan dengan politik, ekonomi, dan sosial budaya;

b. Perseteruan antarumat beragama dan/atau interumat beragama, antarsuku, dan antaetnis;

c. Sengketa batas wilayah desa, Kabupaten/Kota, dan/atau Provinsi;

d. Sengketa sumber daya alam antar masyarakat dan/atau antar masyarakat dengan pelaku usaha; dan

e. Distribusi sumber daya alam yang tidak seimbang dengan masyarakat.

\section{Teori Konflik}

Di dalam tulisan ini, penulis akan menggunakan beberapa teori tentang konflik diantaranya

a. Teori konflik Simon Fisher dan Deka Ibrahim dkk. Teori konflik Simon Fisher dan Deka Ibrahim dkk antara lain adalah: ${ }^{20}$ Teori Kebutuhan dan teori identitas. Teori kebutuhan manusia berasumsi bahwa "konflik yang berakar dalam disebabkan oleh kebutuhan dasar manusia-fisik, mental dan sosial yang tidak terpenuhi atau yang dihalangi". Menurut teori ini bahwa konflik terjadi disebabkan oleh benturan kepentingan antar manusia dalam memperjuangkan pemenuhan kebutuhan dasar baik fisik maupun mental dan sosial yang dalam kondisi tidak terpenuhi.

Sedangkan Teori Identitas berasumsi bahwa: "konflik disebabkan oleh karena identitas yang terancam yang sering berakar pada hilangnya sesuatu atau penderitaan dimasa lalu yang tidak

${ }^{20}$ Fisher Simon, Ibrahim Dekka, dkk., “Working With Conflict: Skill \& Strategies for Action”, (New York: Responding To Conflict, 2002). 
terselesaikan". Menurut teori ini bahwa konflik lebih disebabkan oleh ketidakpuasan kelompok tertentu terhadap kelompok lain atau pemerintah, atas perlakukan tidak adil di masa lalu.

b. Teori fungsional Talcot Parson. Menurut teori ini bahwa "Tertib sosial ditentukan hubungan timbal balik antara sistem-sistem kebudayaan, sosial dan kepribadian. Dengan demikian konflik dapat disebabkan oleh tidak harmonisnya hubungan timbal balik anggota masyarakat sebagai unsur-unsur sistem kebudayaan, sosial dan kepribadian. Berlakunya teori fungsional dari Talcott Parson karena konflik yang terjadi selama ini karena longgarnya ikatan systemsistem yang ada. Ada 4 komponen yang sudah longgar di wilayah rusuh: (1). Nilai-nilai dasar yang dianut masing-masing warga etnis, tidak proporsional memasuki kebudayaan; (2). Status dan hak pribadi tidak terjamin; (3). Prestise dijatuhkan; (4). Pemilikan dan pencaharian tidak terjamin. ${ }^{21}$

c. Teori kebudayaan dominan dari Edwar Bruner diketengahkan Parsudi Suparlan Kemampuan penyesuaian terhadap kebudayaan yang telah mapan. Model Kebudayaan Dominan yang dikembangkan Edwar Bruner dan digunakan Parsudi Suparlan menganalisis kasuskasus Bandung, Ambon dan Sambas menyatakan bahwa: Adanya perbedaan dalam strategi beradaptasi orang Jawa di Bandung dengan strategi adaptasi orang Buton, Bugis dan Makassar (BBM) di Ambon, serta orang Madura di Sambas memperlihatkan mengapa konflik-konflik dapat muncul di kedua daerah terakhir. Dengan kata lain, aturan-aturan dalam kehidupan sosial yang bersumber pada kebudayaan dominan masyarakat setempat tidak diikuti oleh para pendatang dari Buton, Bugis, Makassar dan Madura. ${ }^{22}$

d. Teori Penyimpangan Budaya (Cultural Deviance Theories). Cultural deviance theories memandang kajahatan sebagai seperangkat nilainilai yang khas pada lower class (kelas bawah). Baik strain maupun cultural deviance theories menempatkan penyebab kejahatan pada ketidak beruntungan posisi orang-orang di strata bawah dalam suatu masyarakat yang berbasiskan kelas. Penganut paham ini diantaranya Thomas dan Florian Znaniecki dengan teorinya social disorganization, Robert Park dan Ernest Burgess dengan Natural Urban Areas dan Clifford Shaw dan Henry McKay dengan cultural Transmition. ${ }^{23}$

e Teori Kontrol Sosial. Teori-teori kontrol sosial tertarik pada pertanyaan mengapa sebagian orang taat pada norma. Teori kontrol

\footnotetext{
${ }^{21}$ Rusmin Tumanggor, Jaenal Aripin dan Imam Soeyoeti, 30 Oktober 2010, Analisa Terjadinya Konflik Horizontal di Kalimantan Barat, "Jurnal Konflik Kelompok", <http://www.balitbangham.go.id/ JURNAL/Jurnal\%20HAM\%20I\%20MARIA.pdf>, diakses tanggal 12 September 2012.

${ }^{22}$ Ibid.

${ }^{23}$ Ibid., hal. 67.
} 
sosial memfokuskan diri pada teknik-teknik dan strategi-strategi yang mengatur tingkah laku manusia dan membawanya kepada penyesuaian atau ketaatan kepada aturan-aturan masyarakat. Teori kontrol sosial dikonseptualisasi sebagai: "all-ancompassing, representing practically any phenomenon that leads to conformity to norms" (semua yang mencakup, yang mewakili hampir semua fenomena yang mengarah pada kesesuaian dengan norma-norma). Penganut. $^{24}$ Pengikut teori ini diantaranya adalah Jackson Toby (1957) dengan ide tentang "individual commitment", scott Briar dan Irving Piliavin (1965) memperluas teory Toby, dan Hirschi (1969) dengan bukunya "causes of Delinquency."

f. Teori-teori dari Perspektif Lainnya

1) Conflict Theory. Teori konflik lebih jauh mempertanyakan proses perbuatan hukum itu sendiri. Menurut penganut teori ini bahwa pertarungan (strungle) untuk kekuasaan merupakan suatu gambaran eksistensi manusia. Dalam pertarungan kekuasaan itulah berbagai kelompok kepentingan berusaha mengontrol pembuatan dan penegakan hukum. ${ }^{25}$

2) Radical (Critical) Criminology. Dalam buku "The New Criminology", para kriminolog Marxis dari Inggris yaitu Ian Taylor, Paul Walton dan Jack Young menyatakan bahwa adalah kelas bawah kekuatan buruh dari masyarakat industri dikontrol melalui hukum pidana para penegaknya, sementara "pemilik buruh itu sendiri" hanya terikat oleh hukum perdata yang mengatur persaingan antar mereka. Institusi ekonomi kemudian merupakan sumber dari konflik; pertarungan antar kelas selalu berhubungan dengan distribusi sumber daya dan kekuasaan, dan hanya apabila kapitalisme dimusnahkan maka kejahatan akan hilang. ${ }^{26}$

\section{Penanggulangan Konflik sosial}

Konsep penanganan Konflik menurut ketentuan UU No. 7 Tahun 2012 tentang Penanganan Konflik sosial, meliputi ruang lingkup pencegahan konflik, penghentian konflik dan pemulihan pascakonflik. Upaya yang harus dilakukan antara lain:

a. Pencegahan konflik, meliputi upaya:

1) Memelihara kondisi damai dalam masyarakat;

2) Mengembangkan sistem penyelesaian perselisihan secara damai;

3) Meredam potensi konflik;

\footnotetext{
${ }^{24}$ Ibid., hal. 87.

${ }^{25}$ Ibid., hal. 104.

${ }^{26}$ Ibid., hal. 108-109.
} 
4) Membangun system peringatan dini.

b. Penghentian konflik, meliputi upaya:

1) Penghentian kekerasan fisik;

2) Penetapan status keadaan konflik;

3) Tindakan darurat penyelamatan dan perlindungan korban; dan/atau

4) Bantuan penggunaan dan pengerahan kekuatan TNI.

c. Pemulihan pascakonflik, meliputi upaya:

1) Rekonsiliasi;

2) Rehabilitasi; dan

3) Rekonstruksi.

Hal yang penting juga dalam upaya penanganan konflik adalah kemitraan antara semua pihak yang dilandasi oleh komitmen dari visi dan misi yang harmonis dan sinergis. Konsep kemitraan yang dibangun adalah mengadopsi berbagai nilai-nilai kearifan lokal budaya masing-masing daerah dipadukan dengan konsep kemitraan dan pemberdayaan masyarakat. Polri sebagai aparat negara yang diberi tanggungjawab sebagai komponen utama dalam mewujudkan dan memelihara kamtibmas yang didalamnya termasuk penanganan konflik, mengembangkan konsep Polmas yang diselaraskan dengan nilai-nilai budaya lokal. Dengan demikian, Polri tidak akan berhasil tanpa dukungan dan partisipasi dari masyarakat.

unsur-unsur yang terdapat dalam konflik itu sendiri, yaitu setidaknya memenuhi kriteria sebagai berikut:

a. Ada dua pihak atau lebih yang terlibat;

b. Ada tujuan yang dijadikan sasaran konflik, dan tujuan itulah yang menjadi sumber konflik;

c. Ada perbedaan pikiran, perasaan, tindakan di antara pihak yang terlibat untuk mendapatkan atau mencapai tujuan;

d. Ada situasi konflik antara dua pihak yang bertentangan.

Definisi di atas menunjukkan bahwa konflik tidak selalu berarti kekerasan atau peperangan. Hal itu karena banyak konflik yang sebenarnya masih tersimpan dan belum muncul ke permukaan atau yang sering kita sebut sebagai konflik laten (tersembunyi). Kita bisa menyimpulkan bahwa sekecil apapun perpedaan pendapat dalam masyarakat adalah suatu konflik, walaupun konflik ini belum begitu berdampak negatif kepada masyarakat. Namun demikian, jika hal ini tidak kita kelola dengan baik dan benar, tidak menutup kemungkinan perbedaan pendapat bisa berubah menjadi konflik kekerasan. Setiap masyarakat memiliki cara pandang tersendiri atas konflik yang terjadi di lingkungannya. Cara pandang ini sangat tergantung pada kerangka konseptual umum, atau budaya masyarakat yang melingkupinya. Cara pandang yang berbeda-beda inilah yang kemudian menimbulkan perbedaan makna konflik antara masyarakat yang satu dan lainnya, yang kemudian memunculkan mitosmitos tentang konflik. 
Untuk dapat menyelesaikan konflik yang terjadi di masyarakat, tentunya harus diketahui penyebab konflik yang terjadi. Dengan mengetahui sebabnya, konflik diharapkan segera bisa diselesaikan. Dalam pandangan teori konflik ${ }^{27}$ bahwa masyarakat selalu dalam kondisi perubahan, dan setiap elemen dalam masyarakat memberikan sumbangan bagi terjadinya konflik di masyarakat. Dalam pandangan teori ini bahwa masyarakat disatukan oleh "ketidakbebasan yang dipaksakan". Dengan demikian, posisi tertentu di dalam masyarakat mendelegasikan kekuasaan dan otoritas terhadap posisi yang lain. Fakta kehidupan sosial ini mengarahkan Dahrendorf kepada tesis sentralnya bahwa perbedaan distribusi kekuasaan dan otoritas "selalu menjadi faktor yang menentukan konflik sosial sistematis".

Dengan adanya perbedaan distribusi kekuasaan inilah kemudian memunculkan dua kelompok yang berbeda posisi, yakni kelompok dominan dan kelompok pada posisi subordinat. Mereka yang berada pada posisi dominan cenderung mempertahankan status quo sementara yang berada pada posisi subordinat selalu berupaya mengadakan perubahan terus-menerus. Konflik kepentingan dalam suatu kelompok selalu ada sepanjang waktu, setidaknya yang tersembunyi. ${ }^{28}$

Secara umum penyebab konflik bisa disederhanakan sebagai berikut: ${ }^{29}$
a. Konflik Nilai;
b. Kurangnya Komunikasi;
c. Kepemimpinan yang Kurang Efektif;
d. Ketidakcocokan Peran;
e. Produktivitas Rendah;
f. Perubahan Keseimbangan;
g. Konflik atau Masalah yang Belum Terpecahkan.

Tujuh penyebab konflik di atas adalah penyebab yang sifatnya umum, namun demikian, jika mencermati konflik-konflik yang terjadi khususnya masyarakat di Sulawesi Selatan akhir-akhir ini, bisa merunut, paling tidak ada salah satu penyebab seperti di atas. Dengan mengetahui penyebab terjadinya konflik bisa berharap bahwa konflik akan bisa dikelola, dan diselesaikan dengan baik.

Setelah mengetahui penyebab terjadinya konflik, kini bisa dimulai untuk mencoba berbagai alternatif teoretis untuk menyelesaikan konflik yang tejadi. Secara umum, untuk menyelesaikan konflik dikenal beberapa istilah, yakni: ${ }^{30}$

\footnotetext{
27 Dahrendorf, "Dalam Sosiologi Ilmu Pengetahuan Berparadigma", (Jakarta: Ganada Rajawali Press, 1998), hal. 34.

${ }^{28}$ Geoge Ritzer dan Douglas J Goodman, Teori Sosiologi Modern (Jakarta: Prenada Media, 2004), hal. 156.

${ }^{29}$ Wahyoefiles, 2010, Op. Cit.

${ }^{30}$ Wahyoefiles, 2010, Op. Cit.
} 
a. Pencegahan konflik; pola ini bertujuan untuk mencegah timbulnya kekerasan dalam konflik,

b. Penyelesaian konflik; bertujuan untuk mengakhiri kekerasan melalui persetujuan perdamaian,

c. Pengelolaan konflik; bertujuan membatasi atau menghindari kekerasan melalui atau mendorong perubahan pihak-pihak yang terlibat agar berperilaku positif;

d. Resolusi konflik; bertujuan menangani sebab-sebab konflik, dan berusaha membangun hubungan baru yang relatif dapat bertahan lama di antara kelompok-kelompok yang bermusuhan,

e. Transformasi konflik; yakni mengatasi sumber-sumber konflik sosial dan politik yang lebih luas, dengan mengalihkan kekuatan negatif dari sumber perbedaan kepada kekuatan positif.

Selain memahami istilah-istilah penyelesaian konflik tersebut, adalah juga penting untuk memahami; (1) tahapan konflik; (2) tahap penyelesaian konflik; dan (3) tiga asumsi penyelesaian konflik.31 Tahapan-tahapan konflik tersebut antara lain: potensi oposisi atau keadaan pendorong, kognisi dan personalisasi, penyelesaian-penanganan konflik, perilaku konflik yang jelas, dan hasil. Untuk tahapan penyelesaian konflik adalah pengumpulan data, verifikasi, mendengar kedua belah pihah yang berkonflik, menciptakan kesan pentingnya kerjasama, negosiasi, dan menciptakan kerukunan.

Sementara itu, asumsi-asumsi dalam penyelesaian konflik adalah: ${ }^{32}$

a. Kalah-Kalah; setiap orang yang terlibat dalam konflik akan kehilangan tuntutannya jika konflik terus berlanjut;

b. Kalah-Menang; salah satu pihak pasti ada yang kalah, dan ada yang menang dari penyelesaian konflik yang terjadi. Jika yang kalah tidak bisa menerima sepenuhnya, maka ada indikasi munculnya konflik baru;

c. Menang-Menang: dua pihak yang berkonflik sama-sama menang. Ini bisa terjadi jika dua pihak kehilangan sedikit dari tuntutannya, namun hasil akhir bisa memuaskan keduanya. Istilah ini lebih popular dengan nama win-win solution di mana kedua belah pihak merasa menang dan tidak ada yang merasa dirugikan.

Selain asumsi-asumsi di atas, juga perlu untuk mengetahui strategistrategi untuk mengakhiri konflik. Setidaknya ada sepuluh strategi untuk mengakhiri konflik, yakni: ${ }^{33}$

a. abandoning atau meninggalkan konflik;

b. Avoiding atau menghindari;

\footnotetext{
${ }^{31}$ Simon Fisher, "Mengelola Konflik: ketrampilan dan Strategi Untuk Bertindak", (Jakarta: The British Council, 2001), hal. 293-294.

${ }^{32}$ Wahyoefiles, 2010, Op. Cit.

${ }^{33}$ Ibid.
} 
c. Dominating atau menguasai;

d. Obliging atau melayani;

e. Getting help atau mencari bantuan;

f. Humor atau bersikap humoris dan santai;

g. Postponing atau menunda;

h. Compromise atau berkompromi;

i. Integrating atau mengintegrasikan;

j. Problem solving atau bekerjasama menyelesaikan masalah.

\section{Pendekatan Metode Keadilan Restoratif}

Terdapat banyak model penyelesaian konflik secara teoretis, akan tetapi ada beberapa model yang akan di sajikan dalam tulisan ini yaitu di antaranya adalah sebagai berikut: ${ }^{34}$

a. Model penyelesaian berdasarkan sumber konflik. Dalam model ini, untuk bisa penyelesaian konflik dituntut untuk terlebih dahulu diketahui sumber-sumber konflik: apakah konflik data, relasi, nilai, struktural, kepentingan dan lain sebagainya. Setelah diketahui sumbernya, baru melangkah untuk menyelesaikan konflik. Setiap sumber masalah tentunya memiliki jalan keluar masing-masing sehingga menurut model ini, tidak ada cara penyelesaian konflik yang tunggal;

b. Model Boulding. Model ini menawarkan metode mengakhiri konflik dengan tiga cara, yakni menghindar, menaklukkan, dan mengakhiri konflik sesuai prosedur. Menghindari konflik adalah menawarkan kemungkinan pilihan sebagai jawaban terbaik. Akan tetapi, harus diperhatikan bahwa ini hanya bersifat sementara agar kedua pihak dapat memilih jalan terbaik mengakhiri konflik. Menaklukkan adalah pengerahan semua kekuatan untuk mengaplikasikan strategi perlawanan terhadap konflik. Mengakhiri konflik melalui prosedur rekonsiliasi atau kompromi adalah metode umum yang terbaik dan paling cepat mengakhiri konflik;

c. Model pluralisme budaya. Model ini dapat membantu untuk melakukan resolusi konflik. Misalnya, individu atau kelompok diajak memberikan reaksi tertentu terhadap pengaruh lingkungan sosial dengan mengadopsi kebudayaan yang baru masuk. Inilah yang kemudian disebut sebagai asimilasi budaya. Selain asimilasi, faktor yang bisa membuat kita menyelesaikan konflik adalah akomodasi. Dalam proses akomodasi, dua kelompok atau lebih yang mengalami konflik harus sepakat untuk menerima perbedaan budaya, dan perubahan penerimaan itu harus melalui penyatuan penciptaan kepentingan bersama; 
d. Model intervensi pihak ketiga. Dalam model ini ada beberapa bentuk, yakni coercion, arbitrasi, dan mediasi. Coercion adalah model penyelesaian konflik dengan cara paksaan, di mana masingmasing pihak dipaksa untuk mengakhiri konflik. Arbitrasi adalah penyelesaian konflik dengan cara mengambil pihak ketiga untuk memutuskan masalah yang terjadi, dan keputusan pihak ketiga harus dipatuhi oleh masing-masing pihak. Sementara itu, mediasi berarti pihak ketiga hanya berfungsi untuk menjembatani penyelesaian konflik yang terjadi dalam masyarakat.

Selain model-model penyelesaian konflik yang sudah ada secara teoretis di atas, harus diingat juga bahwa bangsa Indonesia adalah bangsa besar yang memiliki keragaman budaya. Setiap budaya memiliki kearifan-kearifan tersendiri dalam menyikapi permasalahan hidup yang dihadapi, termasuk di dalamnya kearifan dalam menyelesaikan konflik. Berbagai contoh penerapan pendekaran keadilan restoratif melalui metode penyelesaian konflik primitif seperti forum abulo sibatang (Makassar) atau Mabulo sibatang (bugis). System peradilan adat di Papua dan sebagainya. lain: ${ }^{35}$

Ada beberapa Prinsip-prinsip dalam konsep Restorative justice antara

a. Victim support and healing is a priority (Dukungan dan pemulihan Korban merupakan prioritas);

b. Offenders take responsibility for what they have done (Pelanggar bertanggung jawab atas apa yang telah mereka lakukan);

c. There is dialogue to achieve understanding (Ada dialog untuk mencapai kesepahaman);

d. There is an attempt to put right the harm done (Ada upaya untuk mengganti kerugian dengan tepat);

e. Offenders look at how to avoid future offending (Pelanggar melihat bagaimana masa depan untuk menghindari penyesalan/rasa bersalah);

f. The community helps to reintegrate both victim and offender Masyarakat membantu untuk mengintegrasikan kembali antara korban dan pelaku).

Meskipun konsep Restorative Justice dipahami sebagai konsep penyelesaian masalah dalam sistem hukum pidana, akan tetapi konsep Restorative Justice sangat relevan bahkan menjadi konsep dasar yang melandasi Program community Policing.36 Implementasi konsep ini dalam

${ }^{35}$ Mariam Liebmann, “Restorative Justice: How it Works”, (London: Jessica Kingsley Publishers, 2007), hal. 26-27.

${ }^{36}$ Sukardi, 2 Juli 2012, Konsep Restorative Justice Dalam Community Policing (Refleksi Hari Bhayangkara Ke 66 Tahun 2012), "Harian Fajar Makassar", hal. 2 kolom 2-4. Community policing (perpolisian masyarat) merupakan salah satu program Polri yang didasarkan pada prinsip restorative justice dengan metode yang didasarkan pada prinsip-prinsip kesetaraan, kemitraan, rekonsiliasi dan partisipasi. 
kehidupan masyarakat sejalan dengan kebijakan dan rasa keadilan masyarakat. Pada hakekat penyelesaian perkara melalui konsep restorative justice ini, sesungguhnya merupakan konsep yang sudah ada dalam pola penyelesaian perkara pidana adat.37 Pendekatan Restorative justice digunakan juga dalam sistem hukum pidana adat yang sudah berabad-abad lamanya. Sebutlah misalnya dalam sistem hukum pidana adat Papua, mekanisme penyelesaian masalah melalui sidang adat lebih mengutamakan musyawarah mufakat, nilai keadilan tercermin pada pengembalian kerugian korban. Jadi fokus kesepakatan penyelesaian perkara pada pemulihan korban.

Metode penyelesaian perkara Pidana dengan konsep restorative Justice dilakukan melalui konfrensi dan musyawarah melalui forum-forum komunikasi, dialog dan persuasi. Oleh karena itu, metode penyelesaian perkara dengan konsep restorative justice ini memerlukan wadah berupa forum komunikasi penyelesaian masalah yang melibatkan korban, pelaku, masyarakat dan aparat penegak hukum, dengan landasan kepercayaan dan kemitraan. Konsep ini dapat menjamin terpenuhinya rasa keadilan masyarakat, terutama korban, serta memberikan manfaat bagi semua pihak, serta memberikan kepastian hukum bagi pencari keadilan itu sendiri.

Resolusi konflik sosial yang pada dasarnya berakar dari sumber permasalahan social, justru dapat didengan mudah diselesaikan dengan polapola kearifan lokal daerah. Pola-pola tradisional pada dasarnya telah meletakkan pranata-pranata social yang dapat digunakan secara efektif untuk mengidentifikasi berbagai akar masalah dari konflik social yang terjadi, merumuskan dan mengimplementasikan solusi problem solvingnya. Dengan demikian, penyelesaian pasca konflik akan menjadi lebih mudah. Mekanisme ini merupakan prinsip-prinsip resolusi konflik dalam konsep keadilan restorasi yang menitik beratkan pada prinsip rekonsiliasi.

\section{Penutup}

Sebagai kesimpulan dari makalah dapat digambarkan sebagai berikut:

a. Konsekwensi logis dari perubahan sosial sebagai dampak perkembangan teknologi, adalah timbulnya conflict of interest yang memunculkan berbagai pola-pola baru dalam kehidupan sosial yang serba cepat ditengah perbedaan kebudayaan, hal ini mengakibatkan timbulnya disharmoni, konflik-konflik eksternal dan internal, juga disorganisasi dalam masyarakat serta timbulnya kesenjangan sosial, ekonomi, hukum yang tidak sedikit mempengaruhi aspek politik. Peristiwa-peristiwa tersebut memudahkan individu menggunakan pola-pola responsive atau reaksi yang inkonvensional atau menyimpang dari pola-pola umum.

${ }^{37}$ Sukardi, 2012, Penerapan Konsep Restorative Justice dalam hukum Pidana, "Jurnal hukum Univertistas Yapis Jayapura", Vol. 2 Nomor 1, Mei 2012 (ISSN 2088 - 5466), hal. 15. 
Di sisi lain, negara Indonesia dibangun atas landasan hukum (rechtstaat), dimana hukum menjadi supreme konteks penyelenggaraan berbangsa dan bernegara.

b. Konflik diartikan sebagai suatu proses sosial antara dua orang atau lebih (bisa juga kelompok) dimana salah satu pihak berusaha menyingkirkan pihak lain dengan menghancurkannya atau membuatnya tidak berdaya. Konflik dilatarbelakangi oleh perbedaan ciri-ciri yang dibawa individu dalam suatu interaksi.

c. Pendekatan Keadilan Restoratif dalam resolusi konflik pada dasarnya merupakan metode baru khususnya dalam konsep penyelesaian perkara-perkara pidana, akan tetapi menggunakan pola-pola tradisional yang nilai-nilainya telah ada dalam konsep kearifan local masing-masing budaya. Oleh karena itu, penerapan pendekatan keadilan restoratif dalam resolusi konflik, sesungguhnya adalah penggunaan pola-pola tradisional dengan nilai-nilai resolusi konflik yang ada dalam kearifal local budaya, dengan menfokuskan pada pemenuhan keadilan korban, melalui konsep kesetaraan, kemitraan, rekonsiliasi dan partisipasi. 


\section{Daftar Pustaka}

Ahmad Ali, 21 Desember 2011, Restorative (RJ) adalah konsep Modern Hukum Pidana, Harian Fajar, Makassar, Hal 4 kolom 1

Aminuddin Ilmar. 2009. Konstruksi Teori dan Metode Kajian Ilmu Hukum. Hasanuddin University Press, Makassar.

Braithwaite, J. 2002, Restorative Justice and Responsive Regulation, oxford University Press.

Dahrendorf, 1998, Sosiologi Ilmu Pengetahuan Berparadigma Ganada Rajawali Press, Jakarta.

Fisher Simon, Ibrahim Dekka, dkk. (2002) “Working with conflict': Skill \& Strategies for Action. New York.Responding To Conflict..

Friedman, 1997, Law and Society, New Jersey : Prentice-Hall.

Geoge Ritzer dan Douglas J Goodman, Teori Sosiologi Modern (Jakarta: Prenada Media, 2004).

Margarita Zernova, 2007, Restorative Justice, Ideals and Realities, Ashgate Publishing Limited.

Mariam Liebmann, 2007, Restorative Justice: How it Works, Jessica Kingsley Publishers, London.

Mukthi Fadjar, M. 2004. Tipe Negara Hukum. Bayu Media dan In-TRANS, Malang.

Satjipto Rahardjo, 2000, Ilmu Hukum, PT. Citra Aditya Bhakti, Bandung.

Simon Fisher, 2001, Mengelola Konflik: ketrampilan dan Strategi Untuk Bertindak, The British Council, Jakarta.

Sukardi, 2 Juli 2012, Konsep Restorative Justice Dalam Community Policing (Refleksi Hari Bhayangkara Ke 66 Tahun 2012), Harian Fajar Makassar Halaman 2 kolom 2 -4.

2012, Penerapan Konsep Restorative Justice dalam hukum Pidana, Jurnal hukum Univertistas Yapis Jayapura Vol. 2 Nomor 1, Mei 2012 (ISSN 2088 - 5466).

2012, Perspektif Hukum Refleksif Terhadap Konsep Restorative Justice Dalam Pembaharuan Hukum Pidana, Jurnal Ilmu Hukum Ammana gappa Universitas Hasanuddin Makassar Vol. 20 Nomor 2 Juni 2012, Makassar.

, 2014, Legitimacy of The Restorative Justice Principle in the Context of Criminal Law Enforcement, Indonesia Law Review Vol 4 Number 2 May-August 2014 Universitas Indonesia ISSN 2088-8430 [ eISSN 2356-2129. 
Sunyoto Usman, 9 Oktober 2001, Peran Civil Society (masyarakat Madani) dalam tata pemerintahan, Makalah disampaikan pada seminar 'Membangun Kemitraan antara Pemerintah dan Masyarakat Madani untuk Mewujudkan Tata Pemerintahan yang Baik', diselenggarakan oleh Badan Perencanaan Pembangunan Nasional, Jakarta.

Yayasan Pemantau Hak Anak, Children's Human Rights Foundation, Anak yang Berhadapan dengan Hukum dalam Perspektif Hukum Hak Asasi Manusia Internasional.

Manshur Zikri, 1 Juni 2011, Restorative Justice Sebagai Mekanisme Penyelesaian Perkara Yang Mengedepankan Kepentingan Perempuan Sebagai Korban Kekerasan Seksual, Website Internet: <http://manshurzikri.wordpress.com/2011/06/01/restorative-justicesebagai-mekanisme-penyelesaian-perkara-yang-menge-depankankepentingan-perempuan-sebagai-korban-kekerasan-seksual/>, diakses tanggal 25 September 2011

Rusmin Tumanggor, Jaenal Aripin dan Imam Soeyoeti, 30 Oktober 2010, analisa terjadinya konflik horizontal di Kalimantan Barat, Jurnal Konflik Kelompok, Website Internet: <http://www.balitbangham.go.id/ JURNAL/Jurnal\%20HAM\%20I\%20MARIA.pdf>, diakses tanggal 12 September 2012.

Scribd.com, Konflik Sosial di Indonesia, .Website Internet: <http://www.scribd.com/doc/54153599/7-Konflik-Sosial-Di-Indonesia>, diakses tanggal 12 Desember 2012.

Seta Basri, 2012, Konflik Vertikal dan Horizontal di Indonesia, Web Site Internet: <http://setabasri01.blogspot.com/2012/05/pendekatanpendekatan-dalam.html>, diakses tanggal 12 September 2012.

Wahyoefiles, 2010, Konflik dan cara Penbyelesaiannya, Website Internet: $<$ http://www.Wahyoefiles.web.id/2010/11/konflik-dan-carapenyelesaiannya.html>, diakses tanggal 12 September 2012.

UU No. 7 Tahun 2012 tentang Penanganan Konflik sosial (Lembaran Negara Republik Indonesia Tahun 2012 Nomor 116, Tambahan Lembaran Negara Nomor 5313), diundangkan pada tanggal 10 Mei 2012). 